\title{
WORKING GROUP ON FUTURE LARGE SCALE FACILITIES IN ASTRONOMY
}

\author{
H. R. BUTCHER \\ Netherlands Foundation for Research in Astronomy \\ P.O. Box 2, 7990 AA Dwingeloo, Netherlands
}

The idea for a Working Group (WG) on "Future Large Scale Facilities in Astronomy" grew from a discussion held on 20 August, 1994, during the IAU General Assembly in The Hague. The IAU Executive Committee approved its formation in August, 1995, and its composition in October, 1995. The WG will remain active at least until the XXIIIrd General Assembly in Kyoto in 1997. Members are: H. Butcher (Chairman), R. Ekers, B. Fort, N. Kardashev, M. Longair, F. Pacini, L. Rodriguez, G. Swarup, Y. Tanaka, H. Tananbaun, and L. Woltjer (ex officio). The WG carries out its work mostly by email and FAX.

The Working Group's tasks are (i) to promote the early discussion and dissemination of information on potential large scale astronomical projects; (ii) to make and maintain an inventory of planned large scale projects in astronomy; (iii) to further contacts and cooperation between different projects; (iv) to identify areas of duplication and areas of lack of clearly desirable efforts. The WG considers "Large Scale" to be defined as costing about $\mathrm{M} \$ 100$ or more for ground-based projects and more than about $\mathrm{M} \$ 400$ for space based instruments, if built in OECD member countries. These limits are to be relaxed if deemed desirable for projects in non-OECD economies. Finally, the WG focuses especially on projects in their early phases, before they have received financing, and on projects only partially funded and in search of partners.

The principle activities of the WG in its first year have been to prepare an inventory of projects and to plan for discussion sessions on the topic at IAU sponsored meetings.

The Asian Pacific region was identified as a forward looking, possibly fertile area for the development of cooperation, especially if projects can start small to encourage participation. A discussion session on "Future Large Scale Facilities in the Asia-Pacific Region" was organized during the Seventh Asian Pacific Regional IAU meeting held on 19-23 August, 1996, in Pusan, Korea. The situation in astronomy in Korea, in Indonesia and in Taiwan was presented, and possibilities for collaboration in current and future developments were discussed. Particular projects presented included a 4-m optical telescope in India, the Large Mm and Sub-mm Array project in Japan, several projects under discussion in China, instruments possibly to be sited in Antarctica, a pan-regional network of 2-m telescopes and the prospects for a giant optical telescope in the region. Considerable interest was also evident for forming an Asian-Pacific Center for Theoretical Physics. More information about these discussions may be obtained from the organizers (R. Ekers, G. Swarup, and Y. Tanaka).

A one day Joint Discussion (JD 9) has been planned for August 23, 1997, during the IAU General Assembly in Kyoto, Japan. Summary overviews of large scale projects soon to be completed will be combined with discussions of new, as yet unfinanced projects. Debate on additional needs, on perceived duplication and on tactics to promote collaboration and financing will be encouraged.

Below follows a condensed summary of possible future large projects in various states of preparation. Space limitations here preclude inclusion of the large number of space-based and several physics community projects currently under discussion. 
TABLE 1. Some Future Large Projects

\begin{tabular}{|c|c|c|c|c|}
\hline Name & Band & Institutions & Site & Remarks \\
\hline $\begin{array}{l}\text { Large Binocular } \\
\text { Telescope (LBT) }\end{array}$ & Opt-IR & $\begin{array}{l}\text { University of Arizona, } \\
\text { Italy; partners needed }\end{array}$ & Arizona & $\begin{array}{l}\text { Two 8-m mirrors on one } \\
\text { mounting }\end{array}$ \\
\hline Telescopio grande & Opt-IR & $\begin{array}{l}\text { Instituto Astrofysica de } \\
\text { Canarias; partners } \\
\text { needed }\end{array}$ & Canary Islands & $\begin{array}{l}\text { 10-m mirror, proposal } \\
\text { for funding submitted }\end{array}$ \\
\hline Magellan & Opt-IR & $\begin{array}{l}\text { Carnegie Institute; } \\
\text { partners needed }\end{array}$ & Chile & $\begin{array}{l}\text { Two 6.5-m telescopes, } \\
\text { partially funded }\end{array}$ \\
\hline $\begin{array}{l}\text { International } \\
\text { Stratospheric Lab for } \\
\text { Astrophysics (ISLA) }\end{array}$ & Opt-IR & $\begin{array}{l}\text { University of Bochum; } \\
\text { partners needed }\end{array}$ & Airship & $\begin{array}{l}\text { High resolution 4-m } \\
\text { telescope }\end{array}$ \\
\hline $\begin{array}{l}\text { Polar Orbiting } \\
\text { Stratospheric Telescope } \\
\text { (POST) }\end{array}$ & Opt-IR & $\begin{array}{l}\text { Johns Hopkins } \\
\text { University }\end{array}$ & Airship & $\begin{array}{l}\text { High resolution } \\
\text { interferometric telescope }\end{array}$ \\
\hline $\begin{array}{l}\text { Milli-Meter Array } \\
\text { (MMA) }\end{array}$ & mm-submm & $\begin{array}{l}\text { U.S. NRAO; } \\
\text { partners possible }\end{array}$ & Chile & $\begin{array}{l}\text { Synthesis array, } \\
\text { proposal for funding } \\
\text { submitted }\end{array}$ \\
\hline $\begin{array}{l}\text { Large Mm and Sub-mm } \\
\text { Array (LMSA) }\end{array}$ & mm-submm & $\begin{array}{l}\text { Japanese National } \\
\text { Astronomical Obs.; } \\
\text { partners possible }\end{array}$ & (Chile) & $\begin{array}{l}\text { Synthesis array, } \\
\text { proposal for funding } \\
\text { submitted }\end{array}$ \\
\hline $\begin{array}{l}\text { Large Southern Array } \\
\text { (LSA) }\end{array}$ & $\mathrm{mm}$ only & $\begin{array}{l}\text { Cooperation among } \\
\text { four European } \\
\text { countries }\end{array}$ & Chile & $\begin{array}{l}\text { Synthesis array, in study } \\
\text { phase }\end{array}$ \\
\hline $\begin{array}{l}\text { Square Kilometer Array } \\
\text { Interferometer (SKAI) }\end{array}$ & $\mathrm{cm}-\mathrm{m}$ & $\begin{array}{l}\text { Cooperation among six } \\
\text { countries }\end{array}$ & $\begin{array}{l}\text { To be } \\
\text { determined }\end{array}$ & $\begin{array}{l}\text { Synthesis array, in study } \\
\text { phase }\end{array}$ \\
\hline Radio telescope & Radio-submm & $\begin{array}{l}\text { Russia, Uzbekistan, } \\
\text { partners needed }\end{array}$ & $\begin{array}{l}\text { near } \\
\text { Samarkand }\end{array}$ & Steerable 70-m dish \\
\hline
\end{tabular}

